Azam Hajizadeh, Tayebe Bagheri Lotfabad* and Manochehr Bahmaei

\title{
Assessment of aqueous extract of Gypsophila aretioides for inhibitory effects on calcium carbonate formation
}

https://doi.org/10.1515/gps-2019-0014

Received August 08, 2018; accepted November 13, 2018.

Abstract: The aqueous extract of Gypsophila aretioides roots as a "green" or eco-friendly inhibitor of carbonate calcium formation was investigated. The presence of chelating factors such as polyphenol compounds and foaming agents in the plant extract was assessed. Atomic absorption spectroscopy (AAS) demonstrated the ability of G. aretioides extract for dissolution of the carbonate calcium precipitates. Moreover, conductivity measurements revealed that the G. aretioides extract could efficiently retard sedimentation of carbonate calcium from a brine solution of calcium ions exposed to carbonate ions by adding $\mathrm{Na}_{2} \mathrm{CO}_{3}$ to the system solution. In addition, chronoamperometry was performed for a period of $3 \mathrm{~h}$ by polarizing the steel electrode to $-0.9 \mathrm{~V}$ (vs. SCE) at $40^{\circ} \mathrm{C}$. The presence of G. aretioides extract at a concentration of $10 \%(\mathrm{w} / \mathrm{v})$ in chronoamperometry prevented the precipitation of $\mathrm{CaCO}_{3}$ on the steel electrode surface. This was confirmed by scanning electron microscopy (SEM) and energy dispersive X-ray (EDX) analyses which showed an absence of precipitates and lack of calcium ions on the steel electrode after $3 \mathrm{~h}$ chronoamperometry, respectively. However, further studies are required in order to amend the characteristics of $G$. aretioides extract to render it more applicable as an eco-friendly, cost-effective, anti-scale agent for a wide range of industrial applications.

Keywords: scale inhibition; carbonate calcium; Gypsophila aretioides; root extract; chronoamperometry

\footnotetext{
* Corresponding author: Tayebe Bagheri Lotfabad, Department of Industrial and Environmental Biotechnology, National Institute of Genetic Engineering and Biotechnology (NIGEB), Shahrak-e Pajoohesh, Km 15, Tehran-Karaj Highway, Tehran, Iran, P.O. Box: 14965/161. e-mail: bagheril@nigeb.ac.ir, Tel: +98 21 44787321, ORCID: 0000-0003-1801-8367 Azam Hajizadeh, Department of Industrial and Environmental Biotechnology, National Institute of Genetic Engineering and Biotechnology (NIGEB), Tehran, Iran; Faculty of Chemistry, North Tehran Branch, Islamic Azad University, Tehran, Iran Manochehr Bahmaei, Faculty of Chemistry, North Tehran Branch, Islamic Azad University, Tehran, Iran
}

\section{Introduction}

Surface and ground water supplies are exposed to different types of minerals. Some low soluble minerals, in particular, calcium carbonate, exhibit high potential for precipitation from water bodies on the water flow path or on surfaces that are exposed to water, particularly at high temperatures. Moreover, calcium carbonate precipitation occurs on surfaces which are exposed daily to hot or boiling water such as kettles or on bathroom tapware. Calcium carbonate precipitates are known as "scale" in industrial utilities. Scale appearing on heat transfer equipment is a common problem in many industrial processes which deal with high-temperature water such as heat exchangers, boilers and cooling towers [1,2]. The destructive effects of scale and technical problems including reduction of thermal and mechanical efficiencies, deposit-corrosion phenomenon and, foremost, billions of dollars in damage costs to related industries have attracted the attention of researchers in an effort to reduce these problems [2,3].

For the first time, Meyer [4] reported that a number of additives or impurities exhibited marked effects on the growth rate of the crystal facets even at very low concentrations. Subsequent research studies evaluated different chemical scale inhibitors to reduce the formation of calcium carbonate crystals and scales, as summarized by MacAdam et al. [2]. Despite the fact that calcium carbonate deposition can be ameliorated by chemical, physical or biological methods [2], chemical approaches are widely used in various fields of industry. The conventional method of controlling precipitate formations is through the use of chemical compounds known as scale inhibitors. The frequently used scale inhibitors are synthetic polymers such as polyphosphate, polyphosphonate, polycarboxylate and polyacrylic acid $[5,6]$. They can inhibit the formation of the calcium and magnesium precipitates at low concentrations if they are properly employed. However, the release of such chemical materials into the aquatic ecosystem has 
been criticized. Some of the chemical scale inhibitors are not biodegradable and thus accumulate, leading to environmental risks. Moreover, some of the inorganic scale inhibitors released into the receiving water sources are consumed by aquatic plants (e.g. algal species) as nutrients. The subsequent growth of aquatic plants is intensified to the extent that the color of the seawater changes to green in some areas, a phenomenon known as "Eutrophication" or "green soup" disease [7].Substituting alternative low-risk compounds to control the precipitate formation may greatly reduce these environmental risks. In this regard, non-nitrogenous, non-phosphorus, and biodegradable polymers and plant-derived inhibitors are of particular importance $[3,8]$. In the last decade, new green scale inhibitors have been synthesized which are more eco-friendly compared to conventional scale inhibitors [3,9]. Several reports have been made on green scale inhibitors that are environmentally acceptable compared to conventional inhibitors; for example, polyaspartic acid (PASP) [10], polyepoxysuccinic acid (PESA) [11,12], and carboxymethylinulin (CMI) [13] have shown to be the most promising green scale inhibitors to date.

In addition, plant-derived compounds from various plant genera have been studied as possible scale precipitation inhibitors. The use of plant extracts such as olive leaf [14], fig leaf [15], tobacco [16], Paronychia argentea extract [17], palm leaf extract [18] and soybean oil [19] as effective scale inhibitors has been reported. The inhibitory effect of plant extractions on scale deposits has recently been investigated using both dynamic and static tests in experimental studies [3]. Plants are invaluable sources for obtaining natural green materials. Typically, green or eco-friendly compounds have three outstanding properties which include biodegradability, low toxicity for living organisms and extractability from renewable resources [19]. The extraction process is typically simple and inexpensive using easily accessible and widely available plant species $[9,20]$. Therefore, the continued study, development and utilization of plant extracts as effective, eco-friendly sources for debilitating scale formations is very promising.

This study aims to evaluate the capability of aqueous extract of $G$. aretioides to reduce the deposition of calcium carbonate scale. Gypsophila is a widely available, perennial herb [21] which typically grows in calcareous soils and therefore appears to synthesize compounds that can dissolve calcium salts and accumulate them in aerial organs. G. aretioides is a common species of the genus which is widely distributed in northern Iran.

\section{Experimental}

All chemicals and reagents were of analytical grade and prepared by Merck Co., Germany. Plant extract was obtained from $G$. aretioides. The steel sheeting and its analysis were prepared by Fouladrizan Co., Iran, according to the American Iron and Steel Institute (AISI) standards.

\subsection{Gypsophila aretioides roots, collection and aqueous extraction}

The roots of Gypsophila aretioides were collected from steppe regions of Mahdishahr located in Semnan Province, Iran, in July 2015, and identified by Dr. Atefeh Pirani, a plant taxonomist at the Faculty of Science, Department of Biology, Ferdowsi University in Mashhad, Iran. The voucher specimen (3881-TMRC) is deposited at the Herbarium of Traditional Medicine and Materials, Medical Research Center, Shahid Beheshti University of Medical Sciences, Tehran, Iran. G. aretioides, its habitat, aerial parts as well as roots are shown in Figure 1. In order to obtain an aqueous extract from the roots of $G$. aretioides, the roots were washed and then oven-dried at $70^{\circ} \mathrm{C}$ for two hours. Subsequently, they were grated and weighed for $5 \mathrm{~g}$ dried mass which was then transferred to a vessel containing $100 \mathrm{ml}$ distilled water at boiling point and incubated for $15 \mathrm{~min}$, then the solid phase was removed using filter paper (Whatman Grade No. 42). The liquid phase was concentrated and dried to obtain the crude extract of the plant roots.

\subsection{Determination of dominant metals in soil}

Soil samples were collected from the habitat of the roots of $G$. aretioides and analyzed to determine the dominant

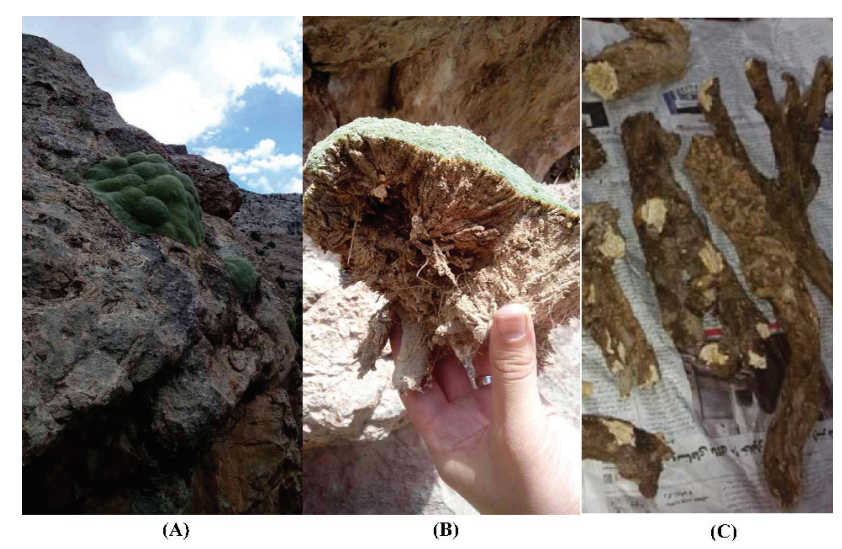

Figure 1: A display of Gypsophila aretioides: (a) habitat (b) aerial parts and (c) the roots. 
existing metal ions. $\mathrm{Ca}^{2+}, \mathrm{Mg}^{2+}, \mathrm{Na}^{+}$and $\mathrm{K}^{+}$were quantified in soil saturated extract by the Mechanical Soil Laboratory of Tehran Transportation Department according to standard methods.

\subsection{Assessment of polyphenol compounds and foaming agents in root extract}

Polyphenols are predominately found in plant-derived substances. They are considered chelating agents which form a complex with calcium cations via their carboxyl and hydroxyl groups, thereby inhibiting the nucleation step and thus the formation of precipitates [3]. The total content of polyphenols was measured using the Folin-Ciocalteu method according to slight modifications by Biju et al. [22]. To carry out the test, G. aretioides extract $(0.2 \%(\mathrm{w} / \mathrm{v}))$ and Gallic acid solutions (20, 40, 60, 80 and $100 \mu \mathrm{g} / \mathrm{ml}$ ) were prepared in distilled water as the sample and standard solutions, respectively. In each experiment, $1 \mathrm{ml}$ extract or standard solution was added to a $25-\mathrm{ml}$ volumetric flask, containing $9 \mathrm{ml}$ distilled water. A blank sample was prepared using distilled water. One ml FolinCiocalteu phenol reagent was added to each flask and shaken for $5 \mathrm{~min}$. Subsequently, $10 \mathrm{ml} 7 \%$ (w/v) $\mathrm{Na}_{2} \mathrm{CO}_{3}$ solution was added to each mixture and the volume was then augmented up to the mark. The mixtures were incubated at room temperature for 90 minutes and the absorbance against the blank sample was determined at $550 \mathrm{~nm}$ with a UV-Visible spectrophotometer. The total content of polyphenols was expressed as $\mu \mathrm{g}$ Gallic acid Equivalents (GAE).

In addition, foaming agents are amphiphilic molecules which form aggregates or micelles at increased concentrations in which calcium ions are entrapped and thus rendered unavailable to carbonate anions, thereby inhibiting formation of precipitates. The presence of foaming agents in the aqueous extract content was qualitatively investigated. Aqueous solution of G. aretioides extract was vigorously vortexed for $2 \mathrm{~min}$ and foam formation was detected.

\subsection{Effect of G. aretioides extract on dissolu- tion of the precipitates}

Dissolution of calcium carbonate precipitates was evaluated in the presence of $G$. aretioides extract. To this end, $33 \mathrm{mg} \mathrm{CaCO}_{3}$ was transferred to different Erlenmeyer flasks and a specified volume of extract stock solution was added to each flask, the volume of each being augmented to $100 \mathrm{ml}$ to make a supersaturated solution at room temperature [17]. Flasks were shaken for $120 \mathrm{~min}$ at $150 \mathrm{rpm}$. Subsequently, the contents of each flask were filtered using Whatman paper to separate the undissolved portion. The filtrate was analyzed for calcium ion concentration by atomic absorption spectroscopy. Calcium ion concentration in each sample was quantified by an atomic absorption spectrometer (varian AA240) equipped with a calcium lamp $(\lambda=239.9 \mathrm{~nm})$. Calcium ion concentrations were calculated from a standard curve for absorption versus calcium ion concentration in a range of 0 to $350 \mathrm{ppm}$ prepared by serial dilutions of the aqueous calcium chloride solution.

The dissolving percentage was estimated for each test as shown in Eq. 1:

$$
\text { Dissolving efficiency }(\%)=\frac{C_{i}}{C_{0}} \times 100
$$

where, $\mathrm{C}_{0}$ is total $\mathrm{mg}$ of calcium ion in supersaturate solution $(120 \mathrm{mg} / \mathrm{l}) . \mathrm{C}_{\mathrm{i}}$ is the concentration of calcium ion in solution after treatment with plant extract. Due to the fact that calcium ions are naturally present in root extract, the amount of $\mathrm{Ca}^{2+}$ ions in aqueous extract solution was determined and considered for calculations of the dissolving efficiency in each sample.

\subsection{Effect of $G$. aretioides extract on inhibi- tion of sedimentation in solution}

In order to determine the inhibitory impact of $G$. aretioides extract on sedimentation of calcium carbonate precipitates from solution, conductivity tests were performed according to Drela et al. [23]. Firstly, all parts of the conductometry set-up including the glass container, mechanical stirrer and conductivity sensor were rinsed with $\mathrm{H}_{2} \mathrm{SO}_{4}(1 \mathrm{M})$, followed by doubledistilled water, to remove any deposits which could lead to measurement error.

To begin the experiment, different volumes of the stock solution of root extract were added to each acid-cleaned flask containing $5 \mathrm{ml}$ of $\mathrm{CaCl}_{2}$ solution $(0.1 \mathrm{M})$. The content of each flask was augmented with double-distilled water up to $100 \mathrm{ml}$. Each mixture was stirred during the titration with $\mathrm{Na}_{2} \mathrm{CO}_{3}(0.1 \mathrm{M})$. For all experiments, conductivity was measured continuously after each addition of $0.2 \mathrm{ml}$ titrant solution to stirring mixture until a constant value of conductivity was attained [23]. 


\subsection{Effect of G. aretioides extract on inhibi- tion of scale formation on steel surface}

The ability of $G$. aretioides extract to reduce the calcium carbonate deposition on the surface of a steel electrode was investigated by chronoamperometry techniques. According to [14], calcium carbonate precipitations on metal surfaces at cathodic potential $(-0.9 \mathrm{~V}$ versus SCE) were measured. This method was based on several oxidation-reduction reactions in the vicinity of the electrodes. When potential is applied, oxygen molecules $\left(\mathrm{O}_{2}\right)$ are reduced to hydroxyl groups $(\mathrm{OH})$ through the reaction 1 .

$$
\mathrm{O}_{2}+2 \mathrm{H}_{2} \mathrm{O}+4 e^{-} \rightarrow 4 \mathrm{OH}^{-}
$$

(Reaction 1)

Consequently, accumulation of $\mathrm{OH}^{-}$around the electrode results in $\mathrm{pH}$ increase which, in turn, causes the calcium carbonate precipitation on the electrode [24] according to the reactions 2 and 3 :

$$
\begin{aligned}
& \mathrm{HCO}_{3}^{-}+\mathrm{OH}^{-} \rightleftharpoons \mathrm{CO}_{3}^{2-}+\mathrm{H}_{2} \mathrm{O} \text { (in bulk) } \\
& \mathrm{Ca}^{2+}+\mathrm{CO}_{3}^{2-} \rightleftharpoons \mathrm{CaCO}_{3} \text { (at theinterface) }
\end{aligned}
$$

(Reaction 2)

(Reaction 3)

where, the carbonate anions and calcium cations participating in these two reactions are provided by the ions present in brine solution in which the chronoamperometry experiment is carried out.

In this regard, G. aretioides extract was evaluated for decreasing the last reaction and therefore restraining or retarding the electrode fouling. A three-electrode cell system was employed for all electrochemical experiments; platinum sheet and saturated calomel electrodes were utilized as the counter and reference electrodes, respectively. The working electrode was steel with a weight percent composition of $\mathrm{C}, 0.081 ; \mathrm{Si}, 0.020$; Mn, 0.4; P, 0.0098, S, 0.0094; Al, 0.056; Ni, 0.031; Co, $0.0061, \mathrm{Cu}, 0.028$; balance Fe. The steel was embedded in epoxy resin in a manner that left one side uncovered (approx. $1 \mathrm{~cm}^{2}$ ) as the exposed surface (Figure 2). Prior to experiments, electrodes were serially washed with DD-water, analar grade (A.R.) ethanol and DD-water to provide a clean surface. Chronoamperometry measurements were performed through a potentiostat PARSTAT 2273 in brine solution $\left(\mathrm{NaCl}, 0.7 \mathrm{M} ; \mathrm{NaHCO}_{3}\right.$, $0.0025 \mathrm{M} ; \mathrm{Na}_{2} \mathrm{SO}_{4}, 0.028 \mathrm{M}$ and $\mathrm{CaCl}_{2}, 0.01 \mathrm{M}, \mathrm{pH}=7 \pm 0.5$ ) including $0,5,10$ or $20 \%$ (w/v) G. aretioides extract [14]. Chronoamperometry records were graphed during a period of $3 \mathrm{~h}$ by polarizing the steel electrode to $-0.9 \mathrm{~V}$ (vs. SCE) at $40^{\circ} \mathrm{C}$ in each test solution. The graphs express the current passing through the steel electrode versus time while calcium salt deposits. To test the reliability and reproducibility of the measurements, duplicate experiments were performed in each case under the same conditions. The formation and crystallography of calcium precipitates on the steel surface were evaluated by scanning electron microscopy (SEM) and X-ray diffraction (XRD) analyses, respectively.

The nucleation, growth, and total surface coverage phenomena occurring at the interface of the cathodically protected steel electrode during the chronoamperometry measurements was studied using scanning electron microscopy. To this end, SEM image was prepared for each steel electrode at the end of chronoamperometry carried out in brine solution containing one of these concentrations $(0,5,10$ and $20 \%(\mathrm{w} / \mathrm{v}))$ of $\mathrm{G}$. aretioides extract.

In addition, crystallography of calcium precipitates on the steel surface was investigated using scanning X-ray diffraction (XRD) analysis and was subsequently compared to the XRD pattern for G. aretioides extract. The latter analysis was carried out in order to recognize whether the sediment on the electrode originated from the formation of calcium carbonate by ions existing in the solution or from the calcium carbonate present in the plant extract. The crystal structure of the samples was investigated using X-ray diffractometer (XRD, Philips, PW1800) with CuK $\alpha$ radiation $(\lambda=1.5418 \AA)$ in the $2 \theta$ range $4^{\circ}$ to $60^{\circ}$.

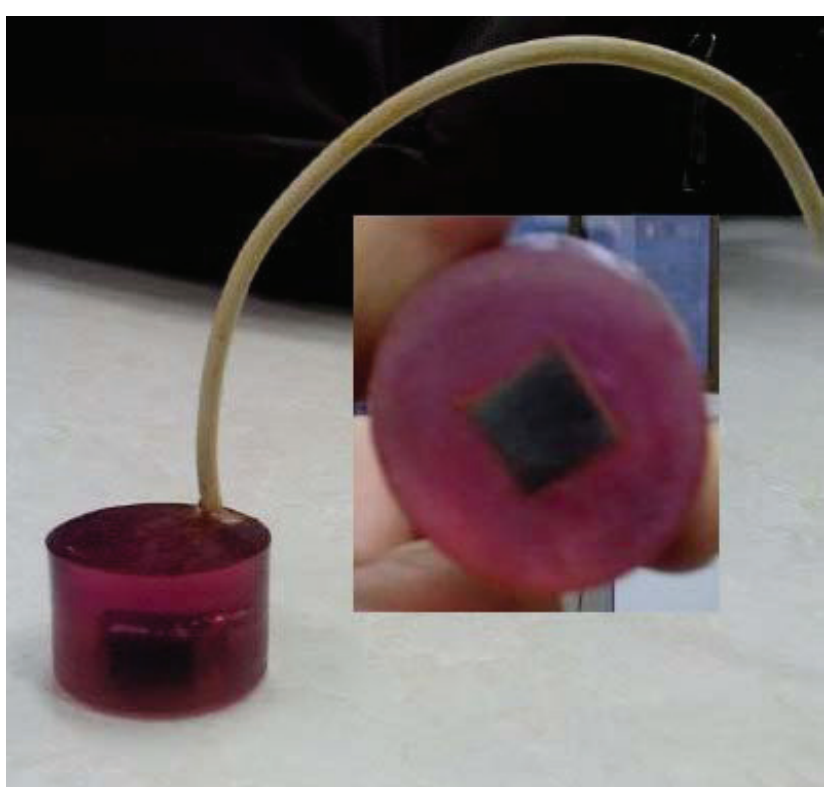

Figure 2: The steel embedded in the epoxy resin used for chronoamperometry experiments. 


\section{Results and discussion}

\subsection{Aqueous extract of $G$. aretioides roots, extraction yield, polyphenol assessment and foaming agents}

G. aretioides in various steps of extraction from root powder to extract form is shown in Figure 3. Results show that $200 \pm 10 \mathrm{mg}$ dried extract was obtained from $5 \mathrm{~g}$ root powder. This means a $4 \%$ extract production yield.

The presence of polyphenols was evaluated using the Folin-Ciocalteu method. In this method, a standard graph was plotted to show the absorption at $550 \mathrm{~nm}$ against the concentration for different Gallic acid solutions (Figure 4). A regression line with $\mathrm{R}$-squared more than 0.99 demonstrated that the standard graph was suitable for estimation of polyphenol concentration from absorption data. A $0.2 \%(\mathrm{w} / \mathrm{v})$ solution of $G$. aretioides extract in distilled water showed absorption of 0.5063 at $550 \mathrm{~nm}$ which is equivalent to approximately $198 \pm 20 \mu \mathrm{g} / \mathrm{ml}$ of polyphenol. Calculations estimated that polyphenol constitutes approximately $10 \pm 1$ percent of $G$. aretioides extract. The presence of polyphenolic substances is expected to be a scheme for capturing the calcium ions

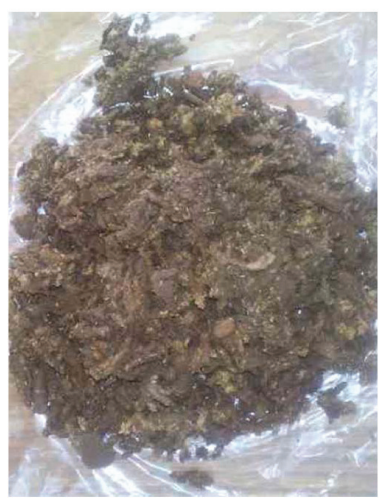

(A)

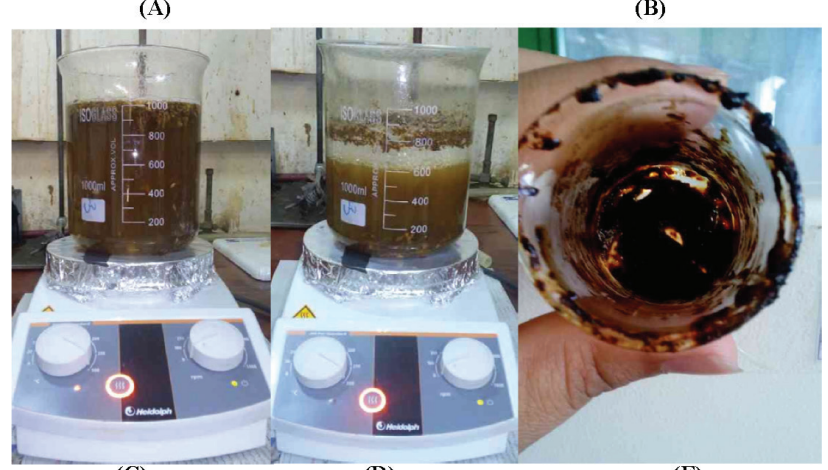

(C)

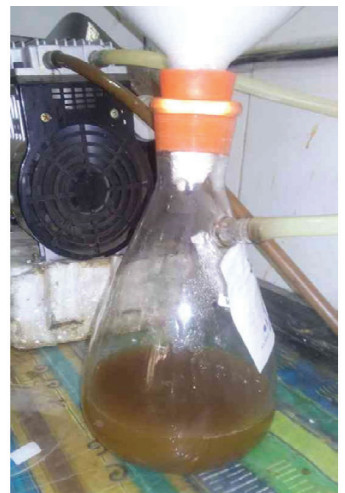

(B)

(E)
Figure 3: An illustration for different stages of Gypsophila aretioides extraction (a) grated roots, (b) aqueous extract, (c) clarified extract, (d) boiling extract and (e) dried extract. and keeping them bound to $\mathrm{CO}_{3}^{2-}$, thus inhibiting calcium carbonate precipitation [14]. Chaussemier et al. claimed that phenolic molecules may inhibit the nucleation step by formation of a complex with calcium cations via their carboxyl and hydroxyl groups [3]. This hypothesis is strengthened when the calcium ions are found both in soils collected from the G. aretioides habitat (Table 1) and an aqueous solution of $G$. aretioides extract detected using atomic absorption spectroscopy (data not shown). This may be due to the fact that $G$. aretioides contains active agents such as polyphenolic substances which may enhance absorption of calcium ions from the habitat soil. This phenomenon is further supported by AbdelGaber [15] where Ficus carica L. grown in calcareous soil conditions showed calcium accumulation in the leaves, and fig leaf extract revealed scale inhibition activity in an alkaline $\mathrm{CaCl}_{2}$ brine solution.

In addition, formation of stable foam with a $2 \mathrm{~cm}$ height in aqueous solution of root powder demonstrated the presence of foaming agents in G. aretioides extract solution. The foaming agents present in plants are usually saponins which may also improve the dispersant properties of the extract which would, in turn, help reduce precipitation of calcium carbonate. The presence of saponin compounds in the Gypsophila genus has been studied and demonstrated previously by Krasteva et al. [21]. These foaming agents are amphipathic substances which form micelles at increased concentrations which, in turn, entrap the calcium cations and restrict their precipitation.

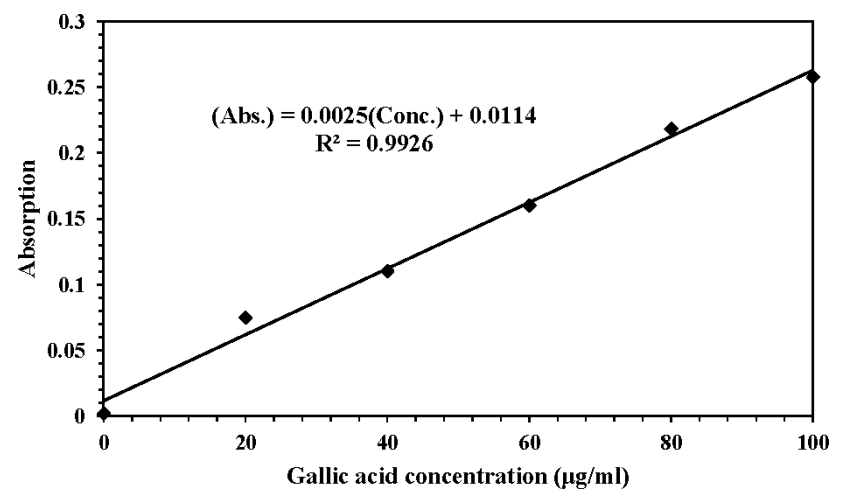

Figure 4: Standard graph for Folin-Ciocalteu method. (Abs.) refers to "Absorption" and (Conc.) is "Gallic acid concentration".

Table 1: Metal ion analysis of soil samples collected from the habitat of the Gypsophila aretioides.

\begin{tabular}{lccc}
\hline $\begin{array}{l}\mathrm{Mg}^{2+} \text { ion } \\
\mathrm{mEq} \mathrm{L}^{-1}\end{array}$ & $\begin{array}{l}\mathrm{Ca}^{2+} \text { ion } \\
\mathrm{mEq} \mathrm{L}^{-1}\end{array}$ & $\begin{array}{l}\mathrm{K}^{+} \text {ion } \\
\mathrm{mEq} \mathrm{L}^{-1}\end{array}$ & $\begin{array}{r}\mathrm{Na}^{+} \text {ion } \\
\mathrm{mEq} \mathrm{L}^{-1}\end{array}$ \\
\hline 3.60 & 24.80 & 0.69 & 1.61 \\
\hline
\end{tabular}




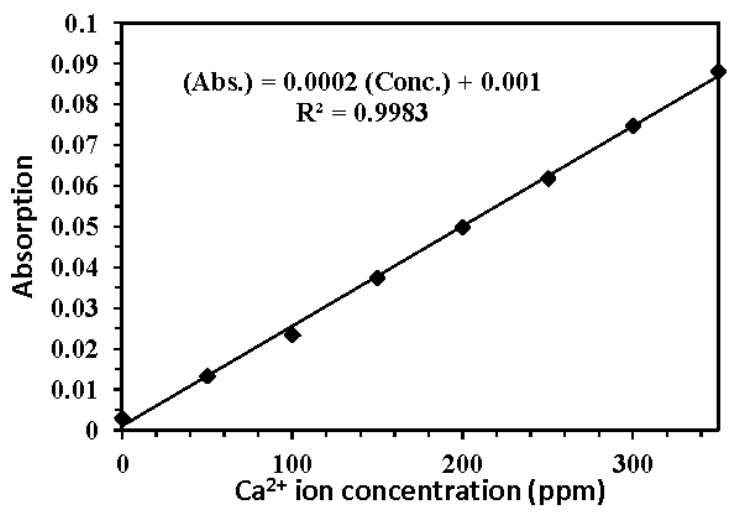

(A)

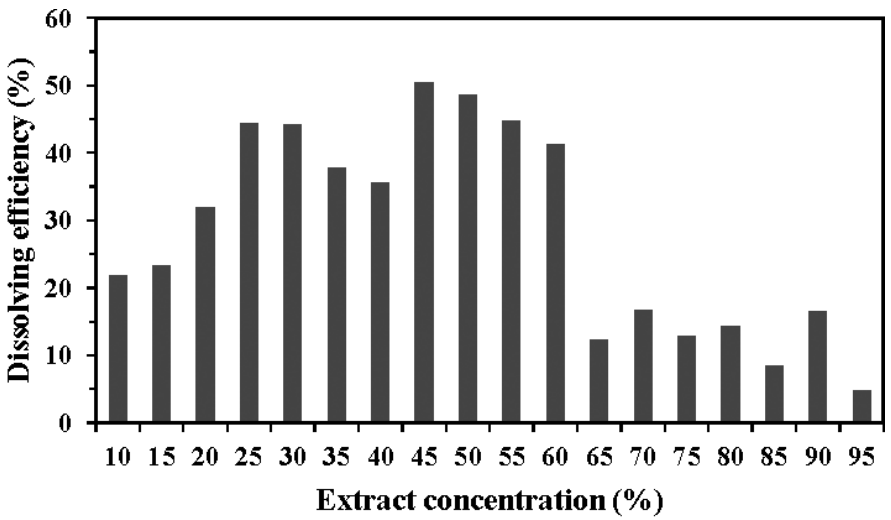

(B)

Figure 5: Dissolving capability of the G. aretioides extract (a) standard graph for absorption versus calcium ion concentration by using the calcium chloride solutions (b) impact of different amount of root extract on percent of solubilized calcium ions. (Abs.) refers to "Absorption" and (Conc.) is "Calcium ion concentration".

\subsection{Dissolution of the precipitates by G. aretioides extract}

The calcium ion concentration in the presence of different amounts of root extract was determined using the atomic absorption method. Regarding the initial concentration of calcium ions in supersaturated solution, the dissolving efficiency of G. aretioides extract is calculated in Eq. 1. A standard graph for absorption versus calcium ion concentration is depicted using calcium chloride solutions (Figure $5 \mathrm{a}$ ). $\mathrm{R}^{2}$ near the 1 demonstrates the linear correlation of absorption and concentration in ranges of 0-350 ppm of calcium ion. The impact of different amounts of root extract on percentage of solubilized calcium ions is shown in Figure 5b. The highest efficiency occurred when the concentration of $G$. aretioides extract fell between 45 to $60 \%(\mathrm{w} / \mathrm{v})$. Increase in extract concentration to more than $60 \%(\mathrm{w} / \mathrm{v})$ reduced dissolution of calcium. This may be due to the fact that once the extract concentration exceeds $60 \%(\mathrm{w} / \mathrm{v})$, calcium ions existing in the root extract reach the equilibrium with solid phase ions and therefore further solubilization of $\mathrm{Ca}^{2+}$ is inhibited in the system.

\subsection{Inhibition of sedimentation in solution by $G$. aretioides extract}

Conductivity measurements in calcium chloride solution in the presence and the absence of different G. aretioides extract concentrations were carried out by means of a sodium carbonate titration method to determine the ability of root extract to retard precipitate formations. This

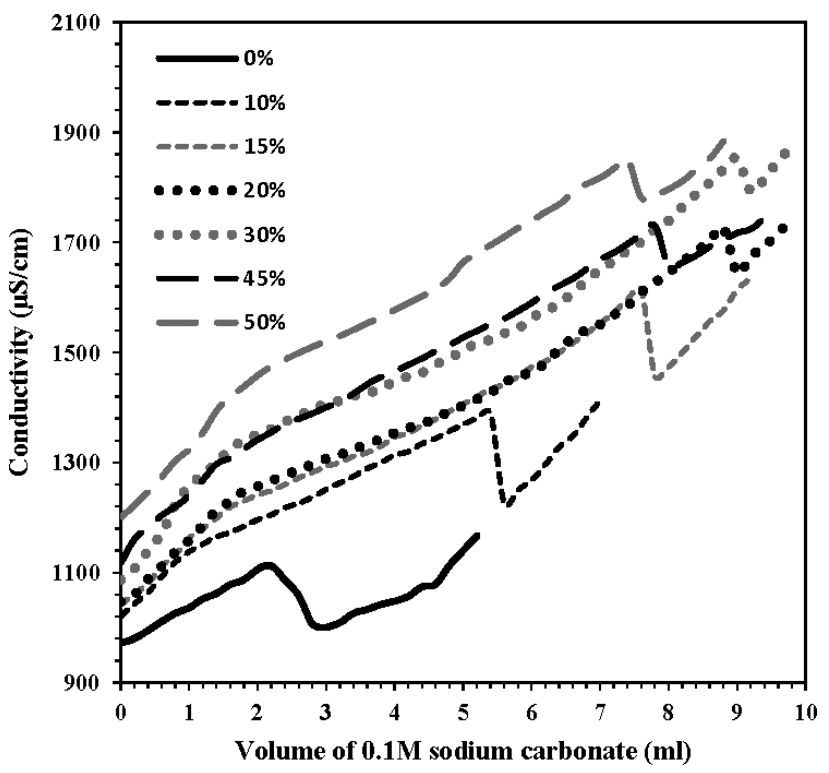

Figure 6: Solution conductivity of $\mathrm{CaCl}_{2}$ versus the amount of sodium carbonate added in the absence and presence of different concentrations of Gypsophila aretioides extract at $25^{\circ} \mathrm{C}$.

rapid method was developed by Drela et al. [23] for the first time. This method is based on the assumption that the adding of $\mathrm{Na}_{2} \mathrm{CO}_{3}$ causes an increase in conductivity. This behavior continues up to supersaturation state where $\mathrm{CaCO}_{3}$ begins to precipitate and thus salting out of $\mathrm{Ca}^{2+}$ from solution occurs which results in decreased conductivity. When precipitation of $\mathrm{CaCO}_{3}$ is completed, adding $\mathrm{Na}_{2} \mathrm{CO}_{3}$ causes $\mathrm{Na}^{2+}$ ions and a raise in conductivity. In this way, the presence of inhibitor substances can postpone the formation of $\mathrm{CaCO}_{3}$ and therefore leads to a drop in conductivity levels.

Figure 6 demonstrates that different amounts of G. aretioides extract can inhibit the formation of calcium 
carbonate in such a way that conductivity reduction is delayed in comparison to experiments performed in the absence of root extract. Similar observations were reported for Punica granatum extracts indicating that the presence of $P$. granatum extract impedes the supersaturation [25]. Furthermore, when the concentration of $G$. aretioides compound exceeded $45 \%(\mathrm{w} / \mathrm{v})$, increasing the extract concentration increased the level of precipitation of $\mathrm{CaCO}_{3}$. This outcome may be due to the existence of calcium ions in the $G$. aretioides extract which can lead to a disturbance in the system and ion equilibrium and consequently render sufficient calcium ions to begin calcium carbonate precipitation.

\subsection{Inhibition of scale formation on steel surface by $G$. aretioides extract}

Chronoamperometry is the most commonly used technique to investigate scaling processes. According to the fundamentals of this technique described in detail in the Experimental section, in the chronoamperometry method, when the potential is applied, the hydroxyl groups are released into the solution and result in precipitation of $\mathrm{CaCO}_{3}$ on the steel electrode. A precipitate layer of $\mathrm{CaCO}_{3}$ forms progressively on the electrode surface, leading to a decrease of current intensity. When the surface of the working electrode is totally covered by scale, the current density reaches a steady-state called the residual current, the value of which depends on the porosity of the scale layer [3].

Inhibitory compounds can prevent the reaction of $\mathrm{CaCO}_{3}$ formation on the electrode. $G$. aretioides extract at different concentrations was added to the brine used in chronoamperometry experiments. In Figure 7, root extract exhibited inhibitory activity against deposition of $\mathrm{CaCO}_{3}$ on the electrode in such a way that current intensity increased once the $G$. aretioides extract was added to the brine. However, effective performance of extract was detected at concentrations below 20\% (w/v). Abdel-Gaber et al. [25] reported similar results when they evaluated the scale inhibition activity of Punica granatum extract. Chronoamperometry measurements showed that $P$. granatum extract impedes the crystal growth stage by retarding the nucleation step, so that the current density increased when the concentration of the $P$. granatum extract increased from 10 to $100 \mathrm{mg} / \mathrm{L}$. Moreover, Belarbi et al. [17] carried out chronoamperometry experiments to test the scale inhibition performance of aqueous Paronychia

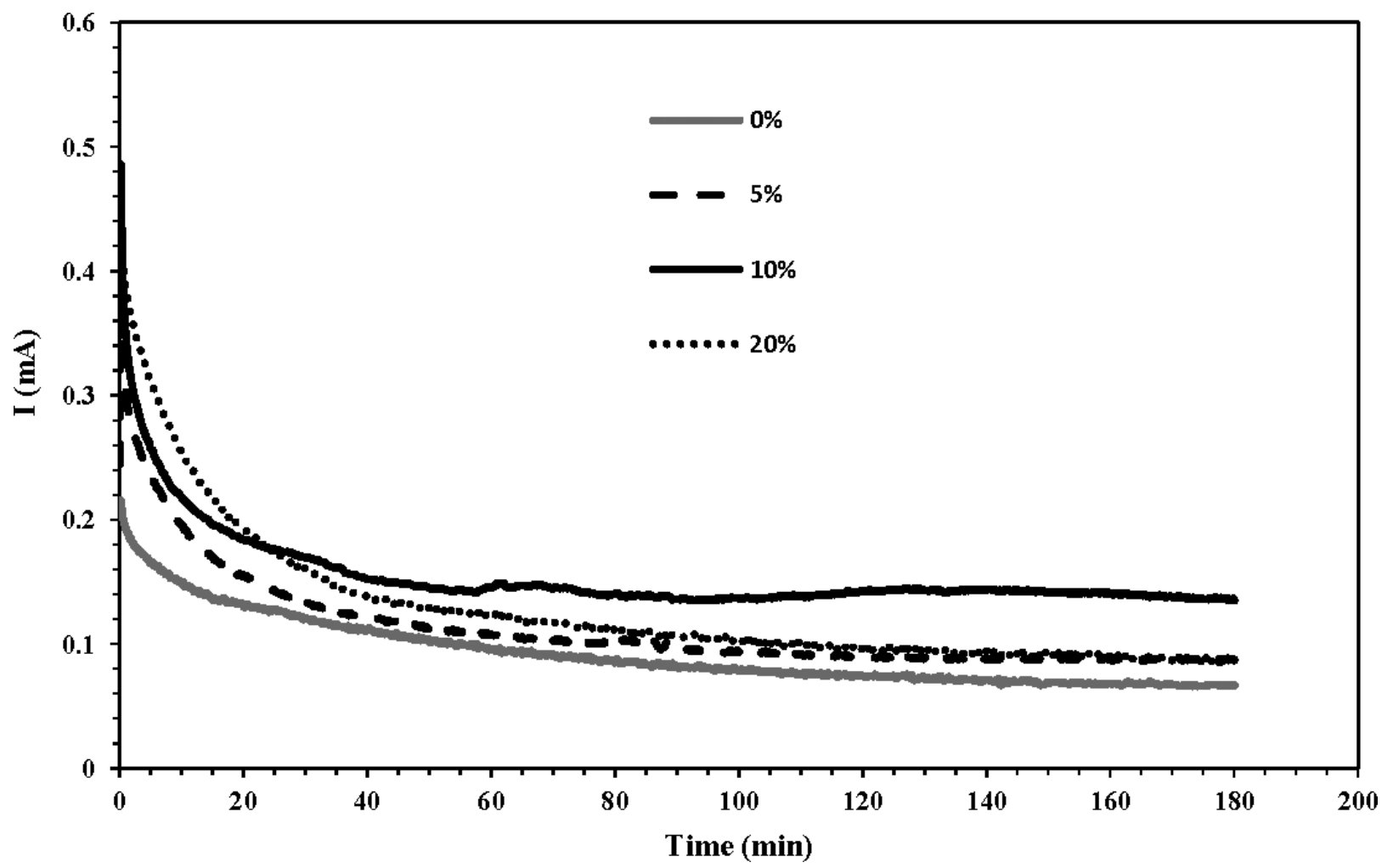

Figure 7: Chronoamperometry curves for steel electrode in the brine solution in the absence and the presence of different concentrations of Gypsophila aretioides extract at $40^{\circ} \mathrm{C}$. 

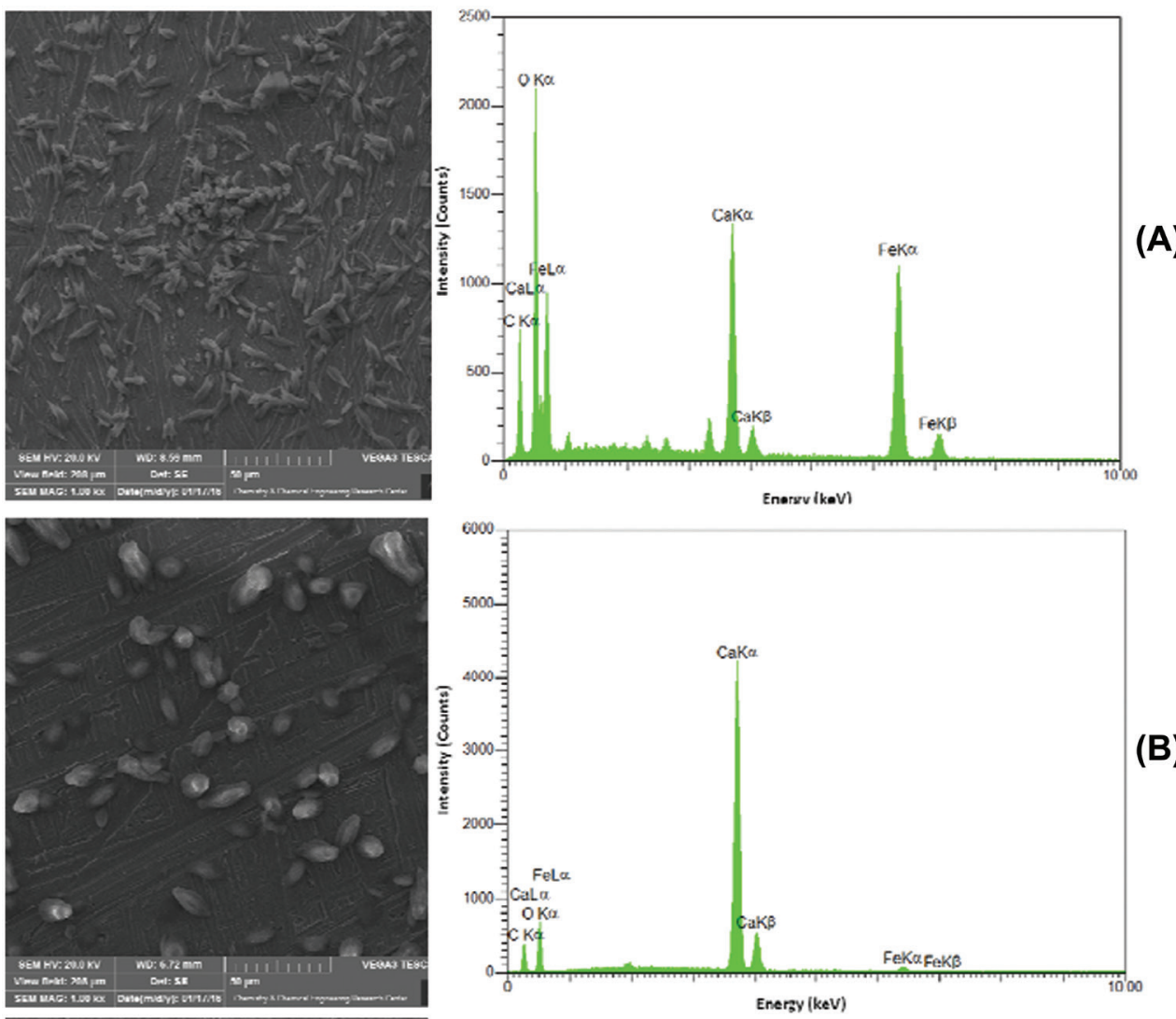

(B)
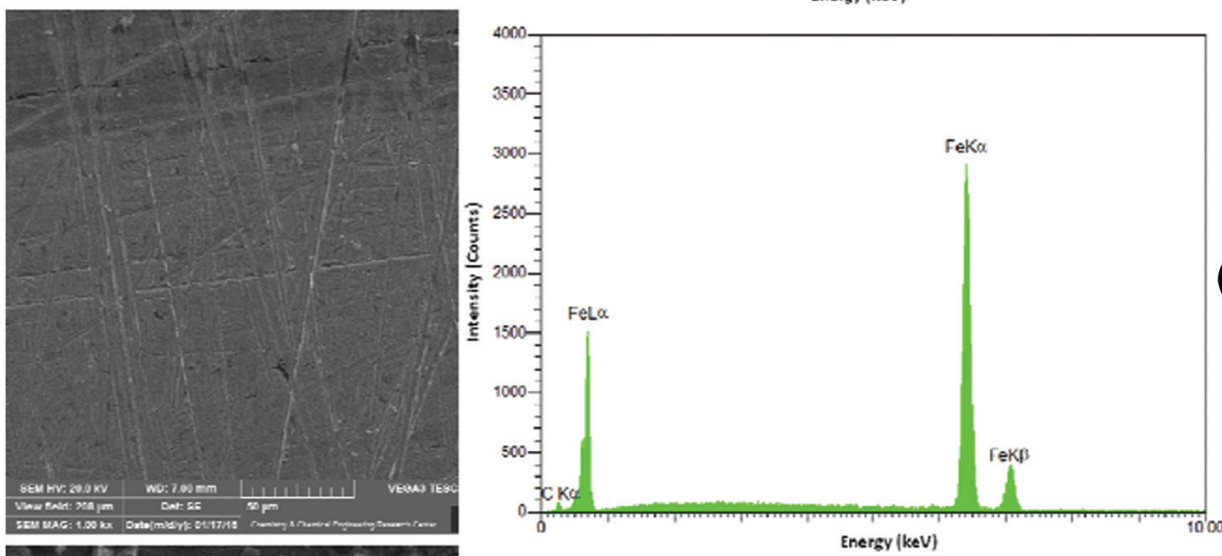

(C)
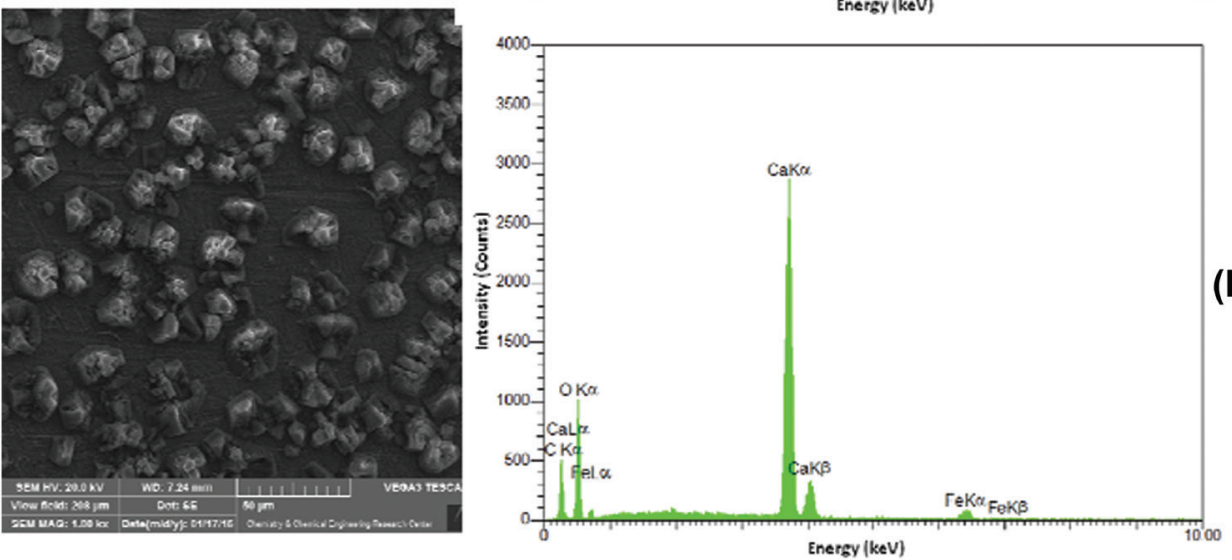

Figure 8: Scanning electron microscopy (SEM) and energy dispersive X-rays spectroscopy (EDX) images of steel electrode after $3 \mathrm{~h}$ chronoamperometry in (a) the absence, and the presence of (b) 5\%, (c) 10 and (d) $20 \%$ Gypsophila aretioides extract. 
argentea extract which showed effective scale inhibition properties at a concentration of $70 \mathrm{ppm}$. Similar observations were recorded for tobacco rob extract [16] and Paronychia argentea [17].

Furthermore, when the concentration of G. aretioides extract exceeded $20 \%(\mathrm{w} / \mathrm{v})$, increasing the extract concentration increased the level of $\mathrm{CaCO}_{3}$ precipitation and therefore the current density reduced. In fact, the presence of $\mathrm{Ca}^{2+}$ ions in the extract leads to accumulation of calcium ions in the system and provides a counterforce against inhibitory tendencies; thus at plant extract concentrations of more than $20 \%(\mathrm{w} / \mathrm{v})$, the amount of precipitate on the electrode is actually more than the amount formed in the presence of $5 \%(\mathrm{w} / \mathrm{v})$ or $10 \%(\mathrm{w} / \mathrm{v})$ extract of G. aretioides.

To further investigate precipitation on the electrode surface, SEM and EDX analyses were prepared for steel electrodes used in each experiment which included 0,5 , 10 and $20 \%(\mathrm{w} / \mathrm{v})$ extract in brine solution, respectively (Figure 8). SEM and EDX data in Figure 8a demonstrate that in the absence of $G$. aretioides extract, a complete surface coverage of scale crystals takes place on the steel electrode. The calcium carbonate crystals decrease with increasing extract concentrations up to $10 \%(\mathrm{w} / \mathrm{v})$ (Figures $8 \mathrm{~b}$ and $8 \mathrm{c}$ ). Moreover, EDX analysis : (Figure 8c-right) revealed that calcium ions are absent on the steel surface when the concentration of $\mathrm{G}$. aretioides extract reached $10 \%(\mathrm{w} / \mathrm{v})$ in the brine solution, the concentration at which no precipitates were found on the steel electrode in SEM imaging (Figure 8c-left). However, Figure 8d shows that in the presence of extract at a concentration of $20 \%(\mathrm{w} / \mathrm{v})$, $\mathrm{CaCO}_{3}$ crystals appeared on the electrode surface. The $\mathrm{X}$-ray diffraction pattern for precipitates scraped from the steel surface at the end of chronoamperometry is presented in Figure 9a. The most intense peak (104)

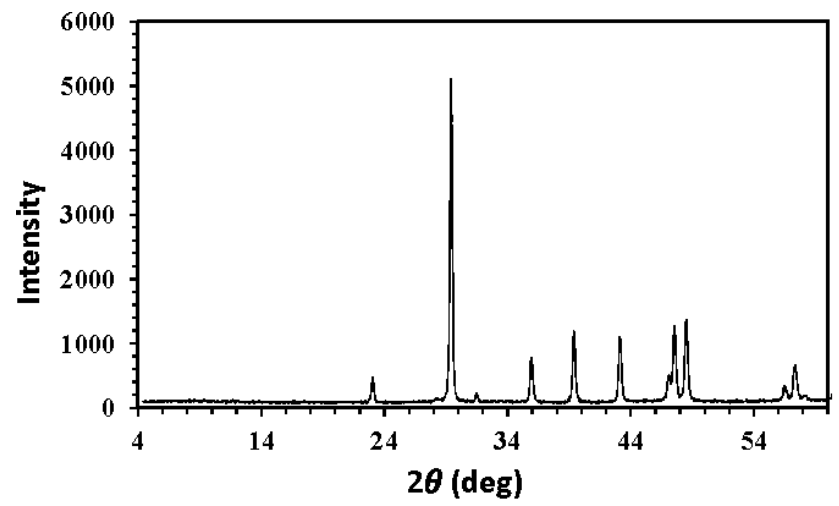

(A) in the diffraction pattern of precipitates reflected pure calcite (most stable form of calcium carbonate) according to JCPDS CARD No. 05-0586 [26]. However, a main broad peak at the vicinity of $2 \theta \simeq 20-24^{\circ}$ (Figure $9 \mathrm{~b}$ ) showed an amorphous form (least stable form of calcium carbonate) [27] for calcium carbonates existing in the plant extract. This discrepancy shows that the crystals on the steel electrode surface in electrochemical experiments have a chemical, not plant, origin. In other words, the precipitates deposited on the steel electrode originated from the reaction of calcium and carbonate ions present in brine when potential was applied in chronoamperometry experiments.

\section{Conclusions}

A number of analyses of $G$. aretioides extract have shown that this extract contains polyphenol and foaming agent compounds. These compounds may be responsible for the scale inhibitory role of $G$. aretioides extract on the formation of calcium carbonate sediment. The inhibitory effect on calcium carbonate scale formation depends on the concentration of G. aretioides extract in the brine solution. According to chronoamperometry experiments, an effective scale inhibition performance in brine solution was obtained at a concentration of $10 \%(\mathrm{w} / \mathrm{v})$. These results were also confirmed by atomic absorption and conductivity measurements. In addition, SEM and EDX analyses implied that calcium carbonate scale formation was affected by the concentration of $G$. aretioides extract. These results indicate the potential of $G$. aretioides extract as an eco-friendly, cost-effective scale inhibitor for the treatment of industrial brine solutions.

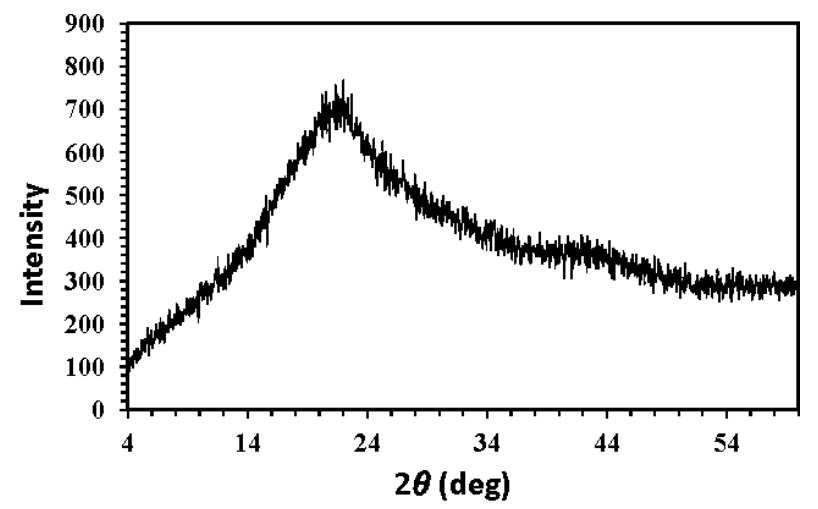

(B)

Figure 9: X-ray diffraction (XRD) patterns for (a) precipitates scraped from the steel surface and (b) G. aretioides extract. 
Acknowledgements: The authors wish to thank the Fouladrizan Co. for preparing the steel sheeting and providing analysis sheets, and particularly Mr. Rashidi for his cooperation.

\section{References}

[1] Li X., Gao B., Yue Q., Ma D., Rong H., Zhao P., et al., Effect of six kinds of scale inhibitors on calcium carbonate precipitation in high salinity wastewater at high temperatures. J. Environ. Sci., 2015, 29, 124-130.

[2] MacAdam J., Parsons S.A., Calcium carbonate scale formation and control. Rev. Environ. Sci. Bio., 2004, 3, 159-169.

[3] Chaussemier M., Pourmohtasham E., Gelus D., Pécoul N., Perrot H., Lédion J., et al., State of art of natural inhibitors of calcium carbonate scaling. Desalination, 2015, 356, 47-55.

[4] Meyer H.J., The influence of impurities on title growth rate of calcite. J. Cryst. Growth., 1984, 66, 639-646.

[5] Kavitha A.L., Vasudevan T., Prabu H.G., Evaluation of synthesized antiscalants for cooling water system application. Desalination, 2011, 268, 38-45.

[6] Ketrane R., Saidani B., Gil O., Leleyter L., Baraud F., Efficiency of five scale inhibitors on calcium carbonate precipitation from hard water: Effect of temperature and concentration. Desalination, 2009, 249, 1397-1404.

[7] Camargo J.A., Alonso Á., Ecological and toxicological effects of inorganic nitrogen pollution in aquatic ecosystems: A global assessment. Environ. Int., 2006, 32, 831-849.

[8] Liu D., Dong W., Li F., Hui F., Lédion J., Comparative performance of polyepoxysuccinic acid and polyaspartic acid on scaling inhibition by static and rapid controlled precipitation methods. Desalination, 2012, 304, 1-10.

[9] Hasson D., Shemer H., Sher A., State of the Art of Friendly "Green" Scale Control Inhibitors. Ind. Eng. Chem. Res., 2011, 50, 7601-7607.

[10] Liu Z., Sun Y., Zhou X., Wu T., Tian Y., Wang Y., Synthesis and scale inhibitor performance of polyaspartic acid. J. Environ. Sci., 2011, 23, S153-S155.

[11] Sun Y., Xiang W., Wang Y., Study on polyepoxysuccinic acid reverse osmosis scale inhibitor. J. Environ. Sci., 2009, 21, S73-S75.

[12] Zhou X., Sun Y., Wang Y., Inhibition and dispersion of polyepoxysuccinate as a scale inhibitor. J. Environ. Sci., 2011, 23, S159-S161.

[13] Johannsen F.R., Toxicological profile of carboxymethyl inulin. Food. Chem. Toxicol., 2003, 41, 49-59.

[14] Abdel-Gaber A.M., Abd-El-Nabey B.A., Khamis E., Abd-ElKhalek D.E., A natural extract as scale and corrosion inhibitor for steel surface in brine solution. Desalination, 2011, 278, 337-342.

[15] Abdel-Gaber A.M., Abd-El-Nabey B.A., Khamis E., Abd-El-Khalek D.E., Investigation of fig leaf extract as a novel environmentally friendly antiscalent for $\mathrm{CaCO}_{3}$ calcareous deposits. Desalination, 2008, 230, 314-328.

[16] Wang H., Gao M., Guo Y., Yang Y., Hu R., A natural extract of tobacco rob as scale and corrosion inhibitor in artificial seawater. Desalination, 2016, 398, 198-207.

[17] Belarbi Z., Gamby J., Makhloufi L., Sotta B., Tribollet B., Inhibition of calcium carbonate precipitation by aqueous extract of Paronychia argentea. J. Cryst. Growth, 2014, 386, 208-214.

[18] Abd-El-Khalek D.E., Abd-El-Nabey B.A., Abdel-kawi M.A., Ramadan S.R., Investigation of a novel environmentally friendly inhibitor for calcium carbonate scaling in cooling water. Desalin. Water. Treat., 2016, 57, 2870-2876.

[19] Miksic B.A., Kharshan M.A., Furman A.Y., Vapor corrosion and scale inhibitors formulated from biodegradable and renewable raw materials. European Symposium on Corrosion Inhibitors 10 SEIC (September 2005, Ferrara, Italy), ctp 83.

[20] Chevalier M., Robert F., Amusant N., Traisnel M., Roos C., Lebrini M., Enhanced corrosion resistance of mild steel in $1 \mathrm{M}$ hydrochloric acid solution by alkaloids extract from Aniba rosaeodora plant: Electrochemical, phytochemical and XPS studies. Electrochim. Acta., 2014, 131, 96-105.

[21] Krasteva I.N., Popov I.S., Balabanova V.I., Nikolov S.D., Pencheva I.P., Phytochemical study of Gypsophila trichotoma wend (Caryophyllaceae). Quím. Nova., 2008, 31, 1125-6.

[22] Biju J., Sulaiman C.T., Satheesh G., Reddy V.R.K., Total phenolics and flavonoids in selected medicinal plants from kerala. Int. J. Pharm. Pharm. Sci., 2014, 6, 406-408.

[23] Drela I., Falewicz P., Kuczkowska S., New rapid test for evaluation of scale inhibitors. Water. Res., 1998, 32, 3188-3191.

[24] Gabrielli C., Keddam M., Perrot H., Khalil A., Rosset R., Zidoune $M$., Characterization of the efficiency of antiscale treatments of water Part I: Chemical processes. J. Appl. Electrochem., 1996, 26, 1125-1132.

[25] Abdel-Gaber A.M., Abd-El-Nabey B.A., Khamis E., Abd-ElRhmann H., Aglan H., Ludwick A., Green Anti-scalent for Cooling Water Systems. Int. J. Electrochem. Sci., 2012, 7, 11930-11940.

[26] Kırboga S., Öner M., The inhibitory effects of carboxymethyl inulin on the seeded growth of calcium carbonate. Colloids Surf. B., 2012, 91, 18-25.

[27] Lee S.W., Kim Y.I., Lee K., Bang J.H., Jun C.W., Jang Y.N., Effect of Serine and Arginine on the Phase Transition from Amorphous $\mathrm{CaCO}_{3}$ and $\mathrm{CaCO}_{3} \cdot 6 \mathrm{H}_{2} \mathrm{O}$ to Calcite Film. Mater. Trans., 2012, 53, 1732-1738. 